\title{
Notes on the importance of proper husbandry in some tropical crops
}

\author{
J. RUINARD 1
}

Department of Crop Production, University of Science and Technology, Kumasi, Ghana

\section{Summary}

The results of a few preliminary experiments concerning the single and combined effect of weed control and fertilizing upon the growth of cocoa in its early youth and the development and yield of groundnuts and maize are presented. They support the opinion that very often on peasant farms in the tropics, where yields are poor and the farmer's income is low, it would be a better and more appropriate remedy to begin by persuading the farmers into giving more care to their crops than to embark immediately upon expensive programmes of radical modernization.

\section{Introduction}

In these days of rapidly increasing need for food and vegetable raw materials in the developing countries of the tropics, higher demands than ever before are made on the farmer's capability to step up his production and to raise the efficiency of his work. In fact nothing less is required from him than to adjust himself in the shortest time possible to standards set by what is called modern agriculture.

In so far as the technical aspects of this so-called modern agriculture are concerned, usually the methods applied in more advanced countries in the temperate zone and at some large estates and pilot projects in the tropics serve as a model. Among these especially the auspicious effect of measures as ample use of fertilizers, mechanization and protection of crops against pests and diseases leaps to the eye. Hence it is no wonder that in most developing countries they are considered characteristic of modern farming, so that every endeavour is made to adopt them.

The present author would certainly not undervalue the great promise these improved techniques hold for raising the efficiency of farming in many parts of the tropics. On the other hand, however, he is inclined to believe that owing to the great hopes one entertains of them, there is often a tendency to overlook the significance of the very first principle basic to all farming: the necessity of applying good husbandry.

Normally there is no danger of that under more advanced farming conditions, since this principle is so strongly interwoven with the conception a good, progressive farmer has of his profession, that he himself as well as the extension and research organizations serving him no longer need think let alone speak about it, and can concentrate all their attention on the more spectacular measures mentioned before. But how

1 Present address: Centre for Agricultural Research in Surinam, Paramaribo, Surinam.

Received for publication: 6th January, 1966. 
different are circumstances in less advanced parts of the world, where it is more often rule than exception to meet with a surprising ignorance of the care crops require! It is quite obvious, therefore, to wonder whether in such regions not first of all every effort must be made to raise the prevailing husbandry standards to a more satisfactory level before the emphasis is shifted to the other group of measures, which are indeed not unjustly so strongly identified with modern agriculture, but unfortunately require large sums of money and, moreover, may possibly not tell to full advantage as long as husbandry standards are so low.

This, of course, is a complex problem which cannot be solved in a moment. In order to obtain in spite of that an idea of its full significance and implications, the author selected two topics, namely weed control and fertilizing, the former representing the group of ordinary maintenance measures, the latter the group of improved techniques considered characteristic of modern agriculture, and examined in various preliminary experiments undertaken at the Kumasi university's experimental farm their single and combined effect upon the development of a tree crop in its early stages, viz. cocoa, and two annual crops, viz. groundnuts and maize.

It was obvious to select weed control and fertilizing from the multitude of appropriate topics. When inspecting small holdings in the tropics in many instances the abundance of weeds surrounding and suppressing the crop plants is very striking. The use of fertilizers is strongly propagated at present, among other things as a consequence of the Freedom from Hunger campaign of the Food and Agriculture Organization of the United Nations.

In this paper the results of these trials are presented and an attempt is made to explain their meaning for the cultivation of the crops concerned.

\section{The cocoa trial}

\subsection{Ge nera 1}

This experiment, a $2 \times 3$ factorial trial in the form of a $6 \times 6$ latin square, was carried out in a shaded nursery, each plot being represented by a wooden box $100 \mathrm{~cm}$ long, $80 \mathrm{~cm}$ wide and $20 \mathrm{~cm}$ deep, to its brim filled with soil and eventually containing 20 cocoa seedlings at $20 \times 20 \mathrm{~cm}$ spacing. Three types of weeding were being tested, viz. no, bad and good weeding, all three of them in the presence as well as in the absence of fertilizers.

The soil used consisted of a homogeneous mixture prepared from the $20 \mathrm{~cm}$ thick upper layer of a piece of land, which had been under a dense and periodically brushed weed vegetation for several years. It was a heavy loam of good texture, the $\mathrm{pH}$ being 6.1 and the available quantities of major nutrients amounting to $0.14 \% \mathrm{~N}$, $0.0008 \% \mathrm{P}, 0.0034 \% \mathrm{~K}, 0.0136 \% \mathrm{Ca}$ and $0.0056 \% \mathrm{Mg}$. Apparently $\mathrm{P}$ was very low and $\mathrm{K}$ low, whereas $\mathrm{N}, \mathrm{Ca}$ and $\mathrm{Mg}$ were adequate. This soil type is quite common in Ghana's cocoa area 1.

Immediately after the boxes had been filled with soil three illegitimate Amelonado seeds were planted at each stand. Four weeks later the number of cocoa plants per stand was reduced to one.

Two and ten weeks after planting fertilizers were broadcast in the appropriate boxes.

1 The assessment of physical and chemical soil characteristics in this and the following trials is from Dr. B. N. Roy, senior lecturer in soil science at the university of Kumasi, to whom the author is indebted for his contribution. 
On both occasions it was a mixture of ammonium sulphate, ammonium phosphate and potash sulphate containing the aequivalent of $120 \mathrm{~kg} \mathrm{~N}, 60 \mathrm{~kg} \mathrm{P}_{2} \mathrm{O}_{5}$ and $60 \mathrm{~kg}$ $\mathrm{K}_{2} \mathrm{O}$ per ha.

In the well-weeded treatments weedings were carried out $2,4,7,10,14$ and 18 weeks after planting and in the badly weeded treatments 7 weeks after planting. A final weeding of all treatments 22 weeks after planting and simultaneous harvest of the cocoa plants brought the experiment to an end. At every weeding all weeds were pulled out, the roots torn loose at the root collar and left in the appropriate boxes, and the aerial parts oven-dried for $48 \mathrm{~h}$ at $50^{\circ} \mathrm{C}$ followed by their weighing and subsequent mulching in the boxes concerned. In all treatments the weed vegetation consisted for the greater part of broad-leaved herbs and for the rest of grasses. The cocoa plants were cut off at soil level, the leaves separated from the stems (the latter had not yet begun to branch) and both leaves and stems oven-dried for the same length of time and at the same temperature as the weeds. Finally the dry leaves and stems were weighed.

For a compilation of weed and cocoa weights together with the results of the statistical analysis the reader is referred to Table 1 and 2. Fig. 1 illustrates the difference in size of the cocoa plants between the worst and the best treatments.

\subsection{W e e d s}

In the well-weeded treatments the weeds were, of course, not given the opportunity to develop into a serious pest. In the badly and non-weeded treatments, however, the weeds had approx. 7 weeks after planting completely overgrown the cocoa. In the non-weeded treatments this remained unchanged throughout the duration of the experiment. The weeding carried out in the badly weeded treatments 7 weeks after planting enabled the cocoa plants to recover partly from the set-back inflicted upon them by the fierce weed competition, but since no further check on weed development was performed, after a short period the cocoa became again overgrown.

In the well-weeded unfertilized treatment the weight of the weeds collected at the successive weedings gradually decreased, firstly because of shading by the cocoa, secondly because the quantity of seeds, rootstocks, etc., available in the soil, diminished. This explains why the period between successive weedings was increased to three and later to four weeks. Virtually the same thing occurred in the well-weeded fertilized treatment, on the understanding that the maxima at 7 and 14 weeks after planting must be due to the application of fertilizers 2 and 10 weeks after planting.

Table 1. Cocoa trial: average dry weight (in grams) per box of the aerial parts of the weeds collected at the various weedings

\begin{tabular}{|c|c|c|c|c|c|c|c|}
\hline \multirow[t]{2}{*}{ Treatments } & \multicolumn{7}{|c|}{ Number of weeks after planting } \\
\hline & 2 & 4 & 7 & 10 & 14 & 18 & 22 \\
\hline No weeding, no fertilizers & - & - & - & 一 & - & - & 250.3 \\
\hline Bad weeding, no fertilizers & - & - & 122.7 & 一 & - & - & 148.0 \\
\hline Good weeding, no fertilizers .. & 4.0 & 4.3 & 4.2 & 1.5 & 1.2 & 1.2 & 1.0 \\
\hline No weeding, with fertilizers .... & - & - & - & - & - & 一 & 548.5 \\
\hline Bad weeding, with fertilizers $\ldots \ldots \ldots$ & - & - & 294.7 & - & - & 一 & 357.7 \\
\hline Good weeding, with fertilizers ... & 3.8 & 4.5 & 8.7 & 1.5 & 3.8 & 1.5 & 1.2 \\
\hline
\end{tabular}




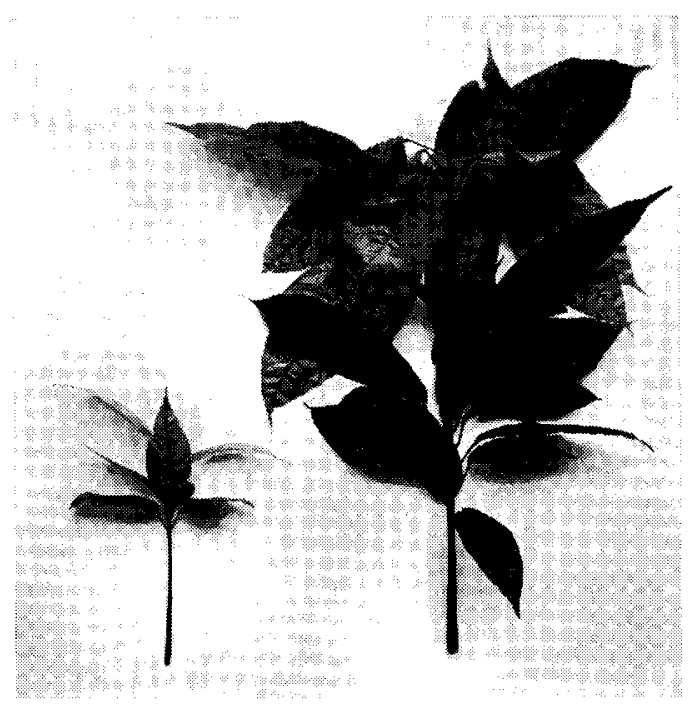

Fig. 1. Cocoa seedlings representing the non-weeded unfertilized treatment (left) and the well weeded fertilized treatment (right); both seedlings cut off at soil level 22 weeks after planting.

Particularly in the badly and non-weeded treatments the weed vegetation showed a considerable response to fertilizing, which on the average amounted to $130 \%$ of the total dry weight of all weeds collected in the corresponding unfertilized treatments.

\subsection{Coc oa}

The cocoa plants showed a much smaller response to fertilizing than the weed vegetation. On the whole the response was just significant and amounted to only $20 \%$ of the average dry weight per plant in the unfertilized treatments.

The weight increments due to better weed control, however, were exceedingly large, both in the absence and in the presence of fertilizers. In both cases the plants from the well-weeded treatment were approx. 5 times and those from the badly weeded treatment approx. 3 times as heavy as the plants from the corresponding non-weeded treatment.

It is interesting to note that the proportion of the stems in the total weight of the plants decreased by better weeding.

With regard to their outward appearance it should be mentioned that in the worst treatments the plants were short, bearing only very few leaves which were, moreover, small and yellowish. In the best treatments, on the other hand, the plants were tall and in the possession of numerous large, green leaves.

\section{The groundnut trial}

\subsection{G e n e r a 1}

This experiment was carried out in the same boxes as the cocoa trial. Also its layout and design were similar. Each box contained eventually 10 groundnut plants at $40 \times 20 \mathrm{~cm}$ spacing. 
The soil used consisted of a 1:1 mixture of remixed soil used before in the cocoa trial and fresh, humic top soil collected in a neighbouring forest. This mixture was described as a heavy loam of good texture, the $\mathrm{pH}$ being 7.0 and the available quantities of major nutrients amounting to $0.42 \% \mathrm{~N}, 0.0056 \% \mathrm{P}, 0.0081 \% \mathrm{~K}, 0.0204 \%$ $\mathrm{Ca}$ and $0.0071 \% \mathrm{Mg}$. These quantities were considered adequate to high.

Immediately after filling the boxes with soil a mixture of ammonium sulphate, ammonium phosphate and potash sulphate was broadcast in the appropriate treatments, containing the aequivalent of $120 \mathrm{~kg} \mathrm{~N}, 60 \mathrm{~kg} \mathrm{P}_{2} \mathrm{O}_{5}$ and $60 \mathrm{~kg} \mathrm{~K} 2 \mathrm{O}$ per ha. Fertilizer application was followed by planting three seeds of the groundnut variety Nigerian White (a bunch type) at each stand. After germination the number of groundnut plants per stand was reduced to one.

In the well-weeded treatments weedings were carried out 2,4 and 6 weeks after planting, in the badly weeded boxes only once at 6 weeks after planting. For a description of the procedure is referred to the cocoa trial. In all treatments the weed vegetation consisted for the greater part of broad-leaved herbs and for the rest of grasses. A final weeding coinciding with the groundnut harvest was not undertaken

Table 2. Cocoa trial: average dry weight per cocoa plant 22 weeks after planting and total dry weight of all weeds produced during those 22 weeks (cocoa and weeds without roots)

\begin{tabular}{|c|c|c|c|}
\hline \multirow[t]{2}{*}{$\begin{array}{l}\text { Treatments, main effects } \\
\text { and interactions }\end{array}$} & \multicolumn{2}{|c|}{$\begin{array}{l}\text { Average dry weight } \\
\text { per cocoa plant }\end{array}$} & \multirow{2}{*}{$\begin{array}{c}\text { Total } \\
\text { dry } \\
\text { weight } \\
\text { of all } \\
\text { weeds } \\
\text { (tons /ha) }\end{array}$} \\
\hline & $\begin{array}{c}\text { Of whole } \\
\text { plant } \\
\text { (grams) }\end{array}$ & $\begin{array}{c}\text { Of stem } \\
\text { as a } \\
\text { percentage } \\
\text { of whole } \\
\text { plant }\end{array}$ & \\
\hline \multicolumn{4}{|l|}{ Treatments : } \\
\hline No weeding, no fertilizers & 1.68 & 49.7 & 3.13 \\
\hline Bad weeding, no fertilizers & 4.68 & 36.6 & 3.38 \\
\hline Good weeding, no fertilizers $\ldots \ldots \ldots \ldots \ldots \ldots \ldots$ & 8.28 & 28.6 & 0.22 \\
\hline No weeding, with fertilizers $\ldots \ldots \ldots \ldots \ldots \ldots \ldots$ & 1.98 & 39.7 & 6.86 \\
\hline Bad weeding, with fertilizers & 5.84 & 36.8 & 8.15 \\
\hline Good weeding, with fertilizers & 9.81 & 33.2 & 0.31 \\
\hline Least sign. difference $(P=0.05)$ & 1.283 & 2.25 & 0.728 \\
\hline \multicolumn{4}{|l|}{ Main effect weeding: } \\
\hline No weeding & 1.83 & 44.7 & 5.00 \\
\hline$\ldots \ldots \ldots \ldots \ldots \ldots$ & 5.26 & 36.7 & 5.76 \\
\hline$\ldots \ldots \ldots \ldots \ldots$ & 9.04 & 30.9 & 0.27 \\
\hline Least sign. difference $(P=0.05)$ & 0.907 & 1.59 & 0.515 \\
\hline \multicolumn{4}{|l|}{ Main effect fertilizing: } \\
\hline Without fertilizers & 4.88 & 38.3 & 2.24 \\
\hline With fertilizers $\ldots$ & 5.88 & 36.6 & 5.11 \\
\hline Least sign. difference $(P=0.05)$ & 0.741 & 1.30 & 0.420 \\
\hline \multicolumn{4}{|l|}{ Interactions : } \\
\hline Bad and no weeding, with and without fertilizers & +0.86 & +10.2 & +1.04 \\
\hline Good and bad weeding, with and without fertilizers & +0.37 & +4.4 & -4.68 \\
\hline Good and no weeding, with and without fertilizers . & +1.23 & +14.6 & -3.64 \\
\hline Least sign. value $(P=0.05) \ldots \ldots \ldots \ldots \ldots$ & 1.814 & 3.19 & 1.029 \\
\hline
\end{tabular}


Table 3. Groundnut trial: average dry weight (in grams) per box of the aerial parts of the weeds collected at the various weedings

\begin{tabular}{|c|c|c|c|}
\hline \multirow[t]{2}{*}{ Treatments } & \multicolumn{3}{|c|}{$\begin{array}{c}\text { Number of weeks } \\
\text { after planting }\end{array}$} \\
\hline & 2 & 4 & 6 \\
\hline No weeding, no fertilizers & $一$ & - & - \\
\hline Bad weeding, no fertilizers & 一 & - & 44.2 \\
\hline Good weeding, no fertilizers .. & 2.1 & 9.8 & 3.0 \\
\hline No weeding, with fertilizers $\ldots \ldots \ldots \ldots$ & 一 & - & - \\
\hline Bad weeding, with fertilizers $\ldots \ldots \ldots$ & - & - & 74.8 \\
\hline Good weeding, with fertilizers $\ldots \ldots \ldots$ & 5.7 & 13.3 & 3.4 \\
\hline
\end{tabular}

Table 4. Groundnut trial: yields of dry shelled nuts, weight per 100 seeds and total dry weight of all weeds produced during the first 6 weeks after planting (weeds without roots)

Treatments, main effects and interactions

$\begin{array}{ccc}\text { Average } & \text { Average } & \text { Average } \\ \text { yields } & \text { weight } & \text { total } \\ \text { of dry } & \text { per 100 } & \text { dry } \\ \text { shelled } & \text { ground- } & \text { weight } \\ \text { ground- } & \text { nut } & \text { of all } \\ \text { nuts } & \text { seeds } & \text { weeds } \\ \text { (tons } / \text { ha }) & \text { (grams) } & \text { (tons } / \text { ha) }\end{array}$

Treatments:

No weeding, no fertilizers

Bad weeding, no fertilizers

$\ldots \ldots \ldots \ldots \ldots \ldots \ldots$

2.14

3.27

3.81

Good weeding, no fertilizers

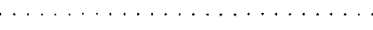

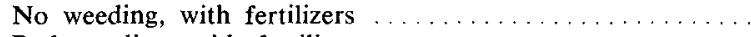

Bad weeding, with fertilizers

3.03
4.15

4.59

0.352

\section{7}

56.1

57.0

57.9

61.4

59.6

4.01

$0 . \overline{55}$

0.19

$0 . \overline{94}$

0.28

Good weeding, with fertilizers
Least sign. difference $(P=0.05)$

No weeding

Bad weeding

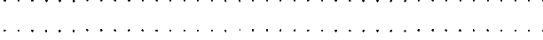

0.249

58.8

58.3

0.74

Least sign. difference $(P=0.05)$

\subsection{7}

3.92

0.204

With fertilizers

$(P=0.05)$

.

Interactions :

Bad and no weeding, with and without fertilizers $\ldots \ldots \ldots$

Good and bad weeding, with and without fertilizers $\ldots \ldots$.

Least sign. value $(P=0.05)$

$\begin{array}{lrr}-0.01 & -0.9 & - \\ -0.10 & -2.7 & -0.30 \\ -0.11 & -3.6 & - \\ 0.498 & 5.68 & 0.196\end{array}$


since the Cercospora disease, which normally during the ripening period of groundnuts causes the crop to drop most of its leaves, in this case also badly affected the weeds and killed many of them.

The groundnuts were harvested 17 weeks after planting. This was followed by drying the pulses, weighing and husking them, weighing the husked seeds and determination of the 100-seeds weight.

Table 3 and 4 contain a compilation of the weed and groundnut weights together with the results of the statistical analysis. The financial outcome is presented in Table 5.

\subsection{W e e d s}

In the well-weeded treatments weeds were, of course, not a serious pest throughout the lifetime of the crop. At the time of the last weeding, 6 weeks after planting, the groundnut plants covered the soil entirely and prevented any further significant weed growth. In the badly and non-weeded treatments the weed vegetation was 6 weeks after planting rather dense, but had not overgrown the crop like in the cocoa trial. At that stage the groundnut plants in these boxes were somewhat smaller than in the well-weeded treatments, but nevertheless they covered the soil almost completely, so that also the badly weeded treatments remained free from further significant weed growth after they had been weeded. In the non-weeded treatments the weeds could unhamperedly continue their growth. Notwithstanding that they did not succeed in wholly overgrowing and suppressing the groundnut plants.

In the badly weeded boxes the response to fertilizing amounted to $71 \%$ of the dry weight of the weeds collected in the corresponding unfertilized treatment. In the wellweeded treatments, though the periods between successive weedings were very short indeed, the response of the weeds to fertilizing was on the average as large as in the badly weeded treatments.

Table 5. Grundnut trial: financial outcome

\begin{tabular}{|c|c|c|c|c|c|c|}
\hline \multirow[t]{2}{*}{ Treatment } & \multicolumn{6}{|c|}{ Per hectare } \\
\hline & $\begin{array}{l}\text { Value } \\
\text { of un- } \\
\text { shelled } \\
\text { nuts } 1\end{array}$ & $\begin{array}{l}\text { Establ. } \\
\text { and } \\
\text { harv. }\end{array}$ & $\begin{array}{l}\text { Fert. } \\
\text { ap- } \\
\text { plic. }\end{array}$ & $\begin{array}{l}\text { Wests } \\
\text { Weed- }\end{array}$ & Total & $\begin{array}{l}\text { Net } \\
\text { return }\end{array}$ \\
\hline No weeding, no fertilizers & 2 & c & 一 & - & c & $-c$ \\
\hline Bad weeding, no fertilizers & $£$ & c & - & $£ 10$ & $£ 10+c$ & $-c$ \\
\hline Good weeding, no fertilizers & $£ 2$ & c & - & $£ 15$ & $£ 15+c$ & $6-c$ \\
\hline No weeding, with fertilizers & $£$ & c & $£ 37$ & - & $£ 37+c$ & $£ 178 \rightarrow c$ \\
\hline Bad weeding, with fertilizers ... & $£ 2$ & c & $£ 37$ & $£ 15$ & $£ 52+c$ & $£ 243-\mathrm{c}$ \\
\hline Good weeding, with fertilizers. & $£ 326$ & $\mathrm{c}$ & $£ 37$ & $£ 22$ & $£ 59+c$ & $£ 267-\mathrm{c}$ \\
\hline \multicolumn{7}{|c|}{$\begin{array}{l}\text { Local price of groundnuts, if sold to the marketing organization, was } £ 71 \text { per ton dry, un- } \\
\text { shelled nuts. }\end{array}$} \\
\hline \multicolumn{7}{|c|}{$\begin{array}{l}\text { The establishment costs (soil tillage, seed, sowing, filling of vacancies, etc.) are in all treatments } \\
\text { the same. The costs of harvesting may be somewhat higher in the better treatments, but the dif- } \\
\text { ferences are certainly negligible. }\end{array}$} \\
\hline \multicolumn{7}{|c|}{3 Based on local fertilizer prices, including costs of mixing, transport and application. } \\
\hline \multicolumn{7}{|c|}{$\begin{array}{l}\text { ot } 200 \text { man-hours per ha, if not fertilized, and } 50 \% \text { more if } \\
\text { of }\end{array}$} \\
\hline
\end{tabular}




\subsection{Ground nuts}

Also in this experiment the crop showed a considerably smaller response to fertilizing than the weeds. Averaged over the three weeding treatments the application of fertilizers resulted in a $30 \%$ increase in yield of dry shelled groundnuts and a $9 \%$ increase in weight per 100 seeds.

The yield increments due to better weeding were larger, both in the absence and in the presence of fertilizers. On the average the badly weeded treatments yielded $45 \%$ more and the well-weeded treatments $65 \%$ more dry shelled groundnuts than the non-weeded ones. Bad weeding showed on the average a $7 \%$ higher 100 -seeds weight than no weeding, but there was in this respect no significant difference between good and bad weeding.

With regard to the outward appearance of the groundnut plants it was observed that a higher yield went with a better vegetative development, the plants being larger with heavier branches and more leaves. Flowering, however, began in all treatments at the same time: $4-4 \frac{1}{2}$ weeks after planting.

The ratio dry weight of shelled nuts: dry weight of unshelled nuts was virtually the same in all treatments, viz. maximum 0.794 , minimum 0.781 and on the average 0.788 .

\section{The first maize trial}

\subsection{G e n e r a 1}

The experiment was laid out in the field as a randomized block trial with 6 treatments in 12 blocks, the treatments being no, bad and good weeding, both in the presence and in the absence of fertilizers. The plot size was $6.30 \times 6.00 \mathrm{~m}$, the distance between maize rows $90 \mathrm{~cm}$ and the distance between adjacent plants in the row (one plant per stand) $30 \mathrm{~cm}$.

The soil was described as a light loam of poor water holding capacity, the $\mathrm{pH}$ just after tillage being 6.7 , and the available quantities of major nutrients in the top soil amounting to $0.28 \% \mathrm{~N}, 0.0010 \% \mathrm{P}, 0.0053 \% \mathrm{~K}, 0.0130 \% \mathrm{Ca}$ and $0.0071 \% \mathrm{Mg}$. $\mathrm{P}$ was said to be very low, $\mathrm{K}$ moderate and $\mathrm{N}, \mathrm{Ca}$ and $\mathrm{Mg}$ adequate. The field had been under light bush for a number of years before it was cleared in early 1963 to grow a crop of maize in the 1963 main rainy season. At the onset of the 1964 main wet season the weed cover was slashed down and the field was ploughed and harrowed, followed by sowing of the maize.

One day before sowing a mixture of ammonium sulphate, ammonium phosphate and potash sulphate was applied in the appropriate plots. It contained the aequivalent of $45 \mathrm{~kg} \mathrm{~N}, 90 \mathrm{~kg} \mathrm{P} \mathrm{P}_{2} \mathrm{O}_{5}$ and $45 \mathrm{~kg} \mathrm{~K} \mathrm{~K}_{2} \mathrm{O}$ per ha and was broadcast in $15 \mathrm{~cm}$ wide strips on either side of the maize rows.

The maize variety used was GS 1, a type developed by the Agricultural Research Institute of the Ghana Academy of Sciences. Just before sowing all weeds emerged after the final harrowing were removed.

In the well-weeded plots weedings were carried out 2, 4, 6 and 8 weeks after sowing, in the badly weeded treatments 7 weeks after sowing. The latter weeding coincided with the commencement of tasseling. In all cases weeding was done according to the farmers' method, that is cutting the plants at soil level using the African hoe and leaving them behind as mulch. About half the weeds were grasses and half broadleaved herbs.

The maize cobs were harvested at the full-grown but still green stage they are com- 
monly used for cooking. The first harvest took place 11 and the second 13 weeks after sowing the crop, immediately followed by weighing the cobs including all husks.

Table 6 contains a compilation of the yield figures together with the results of the statistical analysis. The financial outcome is presented in Table 7.

\subsection{W e e d s}

In the well-weeded plots weeds never became a serious pest. At the time of the weedings in those treatments there were only very few weeds; also in the period between last weeding and second harvest the weed growth was negligible. In the badly and non-weeded treatments the weed vegetation was 7 weeks after sowing dense and at places up to knee-high. At that stage the one and only weeding of the badly weeded treatments was carried out. Thereafter the weed cover remained thin, but at the time of the second harvest its density and height surpassed those of the weeds present in the well-weeded treatments. In the non-weeded plots the weeds could unhamperedly continue their growth, so that at the time of the second harvest the vegetation had become very dense and over knee-high.

Table 6. First maize trial: yield figures

\begin{tabular}{|c|c|c|c|c|c|}
\hline \multirow{2}{*}{$\begin{array}{l}\text { Treatments, main effects } \\
\text { and interactions }\end{array}$} & \multirow[b]{2}{*}{$\begin{array}{c}\text { Number } \\
\text { of } \\
\text { cobs } \\
\text { per } \\
100 \\
\text { prod. } \\
\text { plants }\end{array}$} & \multirow[b]{2}{*}{$\begin{array}{c}\text { Fresh } \\
\text { weight } \\
\text { per } \\
100 \\
\text { cobs, } \\
\text { incl. } \\
\text { husks } \\
(\mathrm{kg})\end{array}$} & \multicolumn{3}{|c|}{ Per hectare } \\
\hline & & & $\begin{array}{c}\text { Number } \\
\text { of } \\
\text { prod. } \\
\text { plants } \\
(\times 100)\end{array}$ & $\begin{array}{c}\text { Number } \\
\text { of } \\
\text { cobs } \\
(\times 100)\end{array}$ & $\begin{array}{l}\text { Fresh } \\
\text { weight } \\
\text { of all } \\
\text { cobs, } \\
\text { incl. } \\
\text { husks } \\
\text { (tons) }\end{array}$ \\
\hline \multicolumn{6}{|l|}{ Treatments: } \\
\hline No weeding, no fertilizers & 109 & 22.1 & 276 & 302 & 6.8 \\
\hline Bad weeding, no fertilizers & 114 & 24.9 & 320 & 364 & 9.1 \\
\hline Good weeding, no fertilizers & 116 & 30.2 & 319 & 368 & 11.1 \\
\hline No weeding, with fertilizers & 112 & 26.7 & 297 & 331 & 8.9 \\
\hline Bad weeding, with fertilizers & 119 & 28.3 & 305 & 364 & 10.3 \\
\hline Good weeding, with fertilizers & 121 & 29.7 & 318 & 385 & 11.5 \\
\hline Least sign. difference $(P=0.05)$ & 3.5 & 1.74 & 15.1 & 20.0 & 0.90 \\
\hline \multicolumn{6}{|l|}{ Main effect weeding: } \\
\hline No weeding $\ldots$ & 110 & 24.4 & 286 & 316 & 7.9 \\
\hline Bad weeding & 116 & 26.6 & 313 & 364 & 9.7 \\
\hline Good weeding & 118 & 29.9 & 318 & 377 & 11.3 \\
\hline Least sign. difference $(P=0.05) \ldots \ldots \ldots \ldots$ & 2.5 & 1.23 & 10.6 & 14.1 & 0.64 \\
\hline \multicolumn{6}{|l|}{ Main effect fertilizing: } \\
\hline Without fertilizers . . . . . . & 113 & 25.7 & 305 & 345 & 9.0 \\
\hline With fertilizers $\ldots \ldots \ldots \ldots$ & 117 & 28.2 & 307 & 360 & 10.2 \\
\hline Least sign. difference $(P=0.05)$ & 2.0 & 1.00 & 8.7 & 11.5 & 0.52 \\
\hline \multicolumn{6}{|l|}{ Interactions : } \\
\hline Bad and no weeding, with and without fertilizers & +2 & -1.2 & -36 & -29 & -0.9 \\
\hline Good and bad weeding, with and without fertilizers . & 0 & -3.9 & +14 & +17 & -0.8 \\
\hline Good and no weeding, with and without fertilizers & +2 & -5.1 & -22 & -12 & -1.7 \\
\hline Least sign. value $(P=0.05)$ & 4.9 & 2.46 & 21.3 & 28.2 & 1.27 \\
\hline
\end{tabular}




\section{The second maize trial}

\subsection{Ge ner a l}

Immediately after the first trial had been harvested a second experiment was laid out at the same site ${ }^{1}$. The treatmentens and the plot arrangement remained exactly the same. The plots were put in readiness by removing all vegetation and all dead material lying on the ground as mulch, followed by hoeing the soil. Carrying away all vegetable material grown during the previous occupation, thus both maize plants and weeds, was considered the best method to keep the differences in chemical and physical soil properties between plots belonging to different treatments, these differences being due to the first trial, as small as possible.

Fertilizing was done in the same way as in the first trial, using an equal quantity of the same mixture. The next day maize was sown, again the variety $G S 1$ at $90 \times$ $30 \mathrm{~cm}$ spacing. At that time all plots were free from weeds.

In the well-weeded treatments weedings were carried out 2, 4, 6, 8, 10 and 14 weeks after sowing, in the badly weeded treatments 7 weeks after sowing, the latter weeding coinciding with the commencement of tasseling. Weeding was always done according to the previously mentioned farmers' method. The composition of the weed vegetation did not markedly differ from that in the first trial.

The maize was harvested 17 weeks after sowing the crop, when the cobs were sufficiently dry. After thorough drying in the sun they were weighed and shelled, followed by weighing the dry grain.

The yield figures and the results of the statistical analysis are presented in Table 8 . The financial outcome is given in Table 9. Fig. 2-5 illustrate the stand of the crop in four of the treatments just before tasseling began.

\subsection{We eds}

The well-weeded plots were weeded so frequently that weeds never became a serious pest. Particularly by the last weedings there were hardly any weeds at all. In the badly and non-weeded treatments, on the contrary, the soil was 7 weeks after sowing covered with a dense weed mat, at places the weeds being knee-high. The former were weeded at that time, but when the maize was harvested the weed vegetation had again become as high and dense as it was before. In the non-weeded treatments there was no check on weed development at all, resulting in an abundancy of weeds at the time of harvest which at places had completely overgrown the maize crop.

The weeds showed a large response to fertilizer application. In the fertilized treatments the vegetation was markedly denser, higher and darker green than in the corresponding non-fertilized treatments, the more so as the frequency of weeding was less.

\section{3. $\mathrm{M}$ a ize}

Both weed control and fertilizing effected large differences in the outward appearance of the maize crop. Height measurements carried out at completion of tasseling, when the longitudinal growth of the maize plants had come to an end, showed that the average length from soil level to leaf joint of the uppermost leaf on the tassel in the

1 Provided the weather is favourable, small farmers in the wet zone of Ghana often grow on the same piece of land a second maize crop immediately after having harvested the first one. 
well-weeded, fertilized treatment was $238 \mathrm{~cm}$ and in the non-weeded, non-fertilized treatment only $115 \mathrm{~cm}$. In the former the maize plants were dark green in colour, in the latter definitely yellow. As far as the other treatments are concerned it suffices to say that the maize crop was markedly darker green and taller where weed control had been better and where fertilized.

Weed control and fertilizing also strongly influenced the number of productive plants per ha. In the worst treatment the number of productive plants amounted to only one third of that in the best treatment, which is a tremendous difference indeed. The number of stands per ha was in this trial 37,000, the average number of productive plants only 24,000. Especially in the non-weeded treatments most of the plants of the non-productive stands had died because of the fierce weed competition. On the whole better weed control led with regard to the number of productive plants per ha to more spectacular results than application of fertilizers.

The number of cobs obtained per 100 productive plants was slightly and the dry grain weight per 100 cobs considerably higher by better weed control and fertilizing. As to the dry grain weight per 100 cobs it is evident that the over-all effect of better weeding was greater than that of fertilizer application.

It follows that there was a substantial response of dry grain yield per ha to both weed control and fertilizing. Averaged over the three weeding treatments fertilizer

Table 8. Second maize trial: yield figures

\begin{tabular}{|c|c|c|c|c|c|}
\hline \multirow{2}{*}{$\begin{array}{l}\text { Treatments, main effects } \\
\text { and interactions }\end{array}$} & \multirow[b]{2}{*}{$\begin{array}{c}\text { Number } \\
\text { of } \\
\text { cobs } \\
\text { per } \\
100 \\
\text { prod. } \\
\text { plants }\end{array}$} & \multirow[b]{2}{*}{$\begin{array}{c}\text { Dry } \\
\text { grain } \\
\text { weight } \\
\text { per } \\
100 \\
\text { cobs } \\
(\mathrm{kg})\end{array}$} & \multicolumn{3}{|c|}{ Per hectare } \\
\hline & & & $\begin{array}{c}\text { Number } \\
\text { of } \\
\text { prod. } \\
\text { plants } \\
(\times 100)\end{array}$ & $\begin{array}{c}\text { Number } \\
\text { of } \\
\text { cobs } \\
(\times 100)\end{array}$ & $\begin{array}{l}\text { Dry } \\
\text { grain } \\
\text { yield } \\
\text { (tons) }\end{array}$ \\
\hline \multicolumn{6}{|l|}{ Treatments: } \\
\hline No weeding, no fertilizers & 100 & 3.2 & 109 & 109 & 0.38 \\
\hline Bad weeding, no fertilizers $\ldots .$. & 101 & 5.2 & 268 & 271 & 1.45 \\
\hline Good weeding, no fertilizers $\ldots$ & 102 & 7.0 & 298 & 304 & 2.17 \\
\hline No weeding, with fertilizers & 101 & 4.8 & 184 & 186 & 0.98 \\
\hline Bad weeding, with fertilizers & 103 & 7.4 & 275 & 283 & 2.11 \\
\hline Good weeding, with fertilizers & 104 & 8.5 & 312 & 325 & 2.78 \\
\hline Least sign. difference $(P=0.05)$ & 0.7 & 0.89 & 32.4 & 33.0 & 0.354 \\
\hline \multicolumn{6}{|l|}{ Main effect weeding: } \\
\hline No weeding ...... & 101 & 4.0 & 146 & 147 & 0.68 \\
\hline Bad weeding $\ldots$ & 102 & 6.3 & 271 & 277 & 1.78 \\
\hline Good weeding & 103 & 7.8 & 305 & 314 & 2.48 \\
\hline Least sign. difference $(P=0.05) \quad \ldots \ldots \ldots \ldots$ & 0.5 & 0.63 & 22.9 & 23.4 & 0.250 \\
\hline \multicolumn{6}{|l|}{ Main effect fertilizing: } \\
\hline Without fertilizers & 101 & 5.1 & 225 & 228 & 1.33 \\
\hline With fertilizers & 103 & 6.9 & 257 & 265 & 1.96 \\
\hline Least sign. difference $(P=0.05) \ldots \ldots \ldots \ldots$ & 0.4 & 0.51 & 18.7 & 19.1 & 0.204 \\
\hline \multicolumn{6}{|l|}{ Interactions : } \\
\hline Bad and no weeding, with and without fertilizers & +1 & +0.6 & -68 & -65 & +0.06 \\
\hline Good and bad weeding, with and without fertilizers . & 0 & -0.7 & +7 & +9 & -0.05 \\
\hline Good and no weeding, with and without fertilizers & +1 & -0.1 & -61 & -56 & +0.01 \\
\hline Least sign. value $(P=0.05) \ldots \ldots \ldots \ldots \ldots$ & 1.0 & 1.25 & 45.8 & 46.7 & 0.500 \\
\hline
\end{tabular}


Table 9. Second maize trial: financial outcome

\begin{tabular}{|c|c|c|c|c|c|c|}
\hline \multirow[t]{3}{*}{ Treatment } & \multicolumn{6}{|c|}{ Per hectare } \\
\hline & \multirow{2}{*}{$\begin{array}{c}\text { Value } \\
\text { of } \\
\text { maize }\end{array}$} & \multicolumn{4}{|c|}{ Costs } & \multirow{2}{*}{$\begin{array}{c}\text { Net } \\
\text { return }\end{array}$} \\
\hline & & $\begin{array}{c}\text { Est- } \\
\text { abl., } \\
\text { harv. } \\
\text { and } \\
\text { shel- } \\
\text { ling }\end{array}$ & $\begin{array}{c}\text { Fert. } \\
\text { ap- } \\
\text { plic. }{ }^{3}\end{array}$ & $\begin{array}{c}\text { Weed- } \\
\text { ing }^{4}\end{array}$ & Total & \\
\hline No weeding, no fertilizers & $£ 13$ & $\mathrm{c}$ & - & - & $\mathbf{c}$ & $£ 13-\mathrm{c}$ \\
\hline Bad weeding, no fertilizers & $£ 49$ & c & - & $£ 8$ & $£ 8+\mathrm{c}$ & $£ 41-\mathrm{c}$ \\
\hline Good weeding, no fertilizers & $£ 74$ & $\mathrm{c}$ & - & $£ 18$ & $£ 18+c$ & $£ 56-c$ \\
\hline No weeding, with fertilizers & $£ 33$ & c & $£ 28$ & - & $£ 28+c$ & $£ 5-\mathrm{c}$ \\
\hline Bad weeding, with fertilizers & $£ 72$ & c & $£ 28$ & $£ 10$ & $£ 38+c$ & $£ 34-\mathrm{c}$ \\
\hline Good weeding, with fertilizers .. & $£ 95$ & c & $£ 28$ & $£ 22$ & $£ 50+c$ & $£ 45-c$ \\
\hline
\end{tabular}

1 Local price of maize, if sold at the farm, was $£ 34$ per ton dry grain.

2 The establishment costs (soil tillage, seed, sowing, filling of vacancies, etc.) are in all treatments the same. The costs of harvesting may be samewhat higher and the costs of shelling will certainly be higher in the better treatments, but it is felt that these differences are negligible if compared to the total amount involved in establishment, harvest and shelling.

$s$ Based on local fertilizer prices, including costs of mixing, transport and application.

4 Based on actual figures; a single weeding of a well-weeded plot would require 60 man-hours per ha and of a badly weeded plot 160 man-hours per ha, if not fertilized, and $25 \%$ more if fertilized.

application resulted in an $47 \%$ increase in yield. The yield increments due to better weeding were considerably larger, both in the absence and in the presence of fertilizers. On the average the badly weeded treatments yielded $162 \%$ more and the wellweeded treatments $265 \%$ more than the non-weeded ones.

\section{Discussion}

\subsection{Cocoa}

Recently the author published some figures on the performance of ordinary Amelonado cocoa in a well maintained field trial undertaken in West New Guinea (RuINARD, 1964). This cocoa, being of West African origin and not having received any exceptional treatment which might lead to spectacular results, came into bearing two years after planting the seeds and yielded during the next twelve months approx. $1,000 \mathrm{~kg}$ dry cocoa per ha. These figures, though not in itself sensational, are unbelievably auspicious if compared to those normally obtained at West African small holdings, where the same Amelonado usually grows slowly, consequently does not come into bearing until 5-7 years from planting and does not produce more than, on an average, 200-300 kg dry cocoa per ha per annum. Yet these small holdings are the source of almost $70 \%$ of the world's total cocoa output.

Does this mean that natural conditions for cocoa growing in West New Guinea and other parts of the tropics where Amelonado shows good growth and yields, including properly maintained plantings of various research institutes in West Africa itself, are so much superior to those prevailing at the average West African cocoa farm? No doubt the answer is negative. It is considered beyond dispute that the low standard 


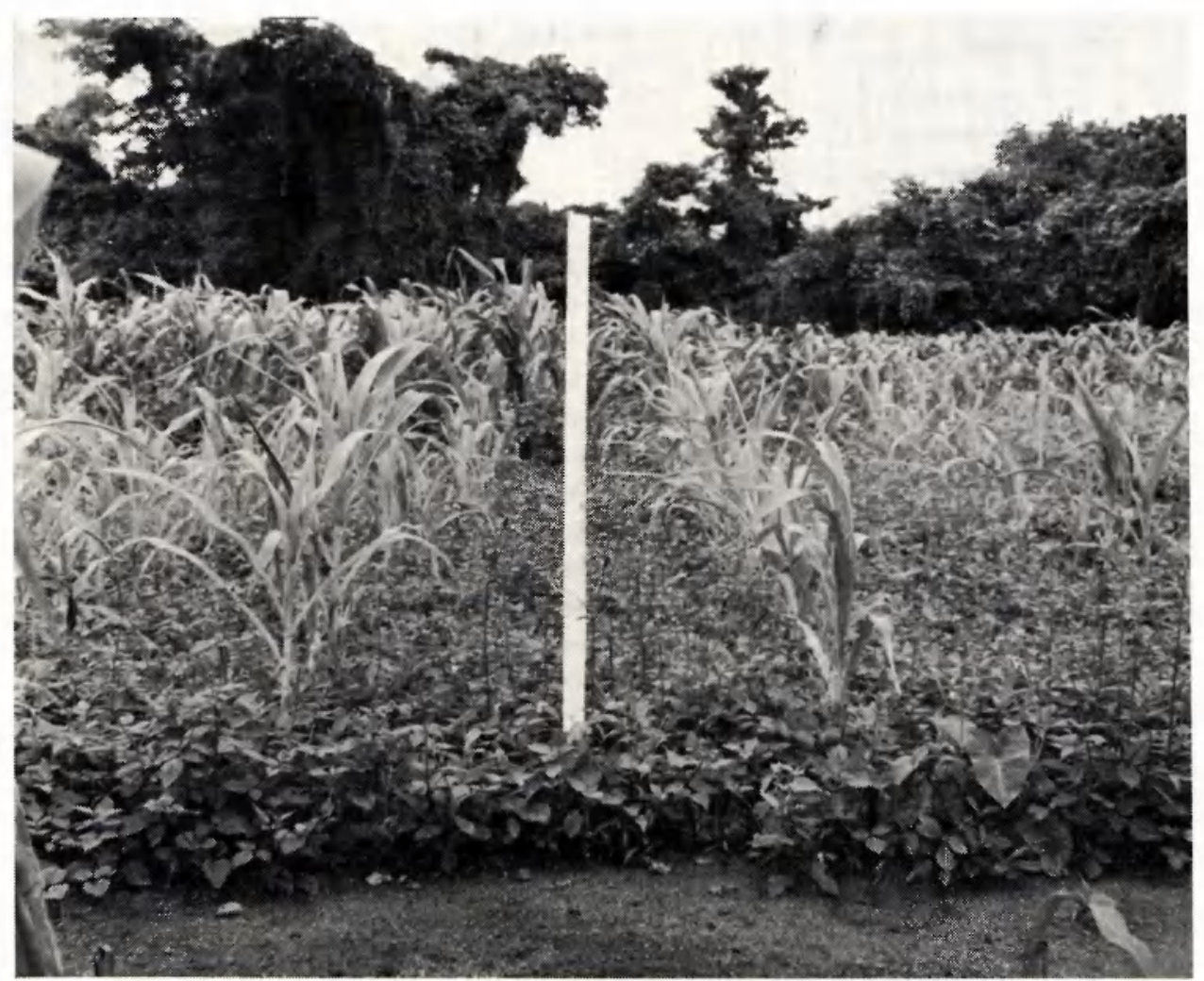

Fig 2. No weeding, no fertilizers. Fig. 2 to 5 : photos of four sample plots of the second maize trial six weeks after sowing the crop. The length of the white stick in front is $100 \mathrm{~cm}$.

of field practices in use at such farms is largely responsible for the cocoa's poor performance and, indeed, cannot but depress it to a mere fraction of the crop's potentiality.

One of the most striking aspects of the agronomic methods applied at small holdings is the little attention the young cocoa receives. Practically it is left to fend for itself until the time comes that the crop starts bearing, the only aid consisting of incidental weedings, at best two or three per year, and removal of redundant shade trees. Hence the cocoa is particularly in its early youth continually implicated in a violent struggle for survival with a luxuriant weed vegetation.

The above trial has clearly demonstrated that under such conditions fertilizer application may not be expected to result in considerably better growth of the young cocoa. Proper weeding, on the other hand, thus safeguarding the crop against the exhaustive and destructive competition of weeds, tends to effect a spectacular improvement.

\subsection{Groundnuts}

According to the financial account presented in Table 5 in this particular experi- 


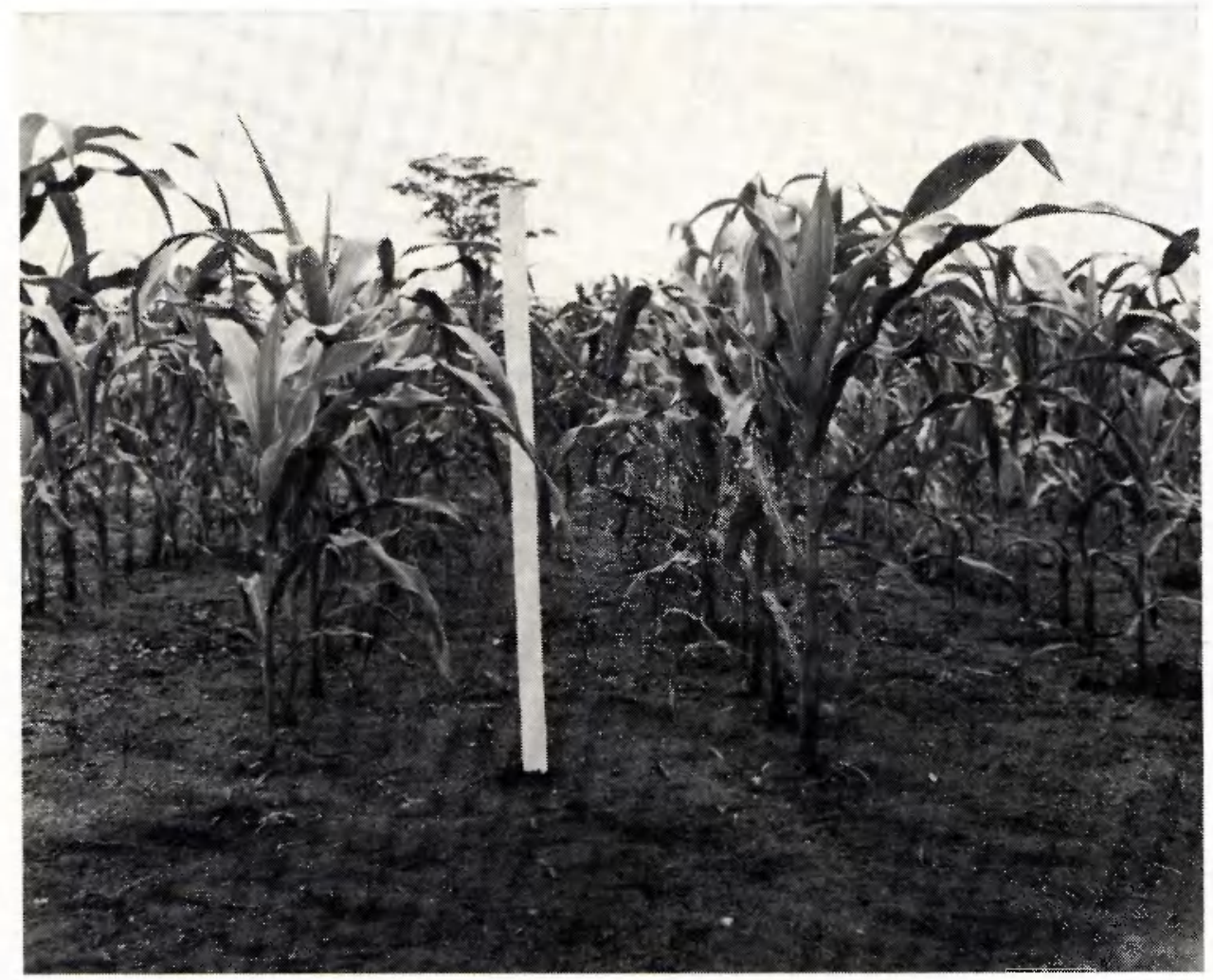

Fig. 3. Good weeding, no fertilizers.

ment both better weed control and fertilizing always resulted in a substantially higher net return. On the whole, however, weeding turned out to be a more profitable measure than fertilizing. In the absence of fertilizers an expenditure on weeding of $£ 10$ per ha resulted in a net return increment of $£ 70$ per ha, whereas an additional weeding expenditure of $£ 5$ per ha increased the net return by another $£ 34$ per ha. Fertilizing, on the other hand, which costed in this case $£ 37$ per ha, resulted in an average net return increment of only $£ 19$ per ha.

\section{3. $\mathrm{M}$ a i z e}

Contrary to what happened in the groundnut experiment, in both maize trials the application of fertilizers reduced the farm's net return, irrespective of the type of weeding treatment. Improved weed control, however, proved to be a lucrative investment, although the extra profits were not as high as in the groundnut trial.

\section{Conclusions}

The aim of the experiments reported on in this paper was to examine the single

Neth. J. Agric. Sci., Vol. 14 (1966) No. 4 (November) 


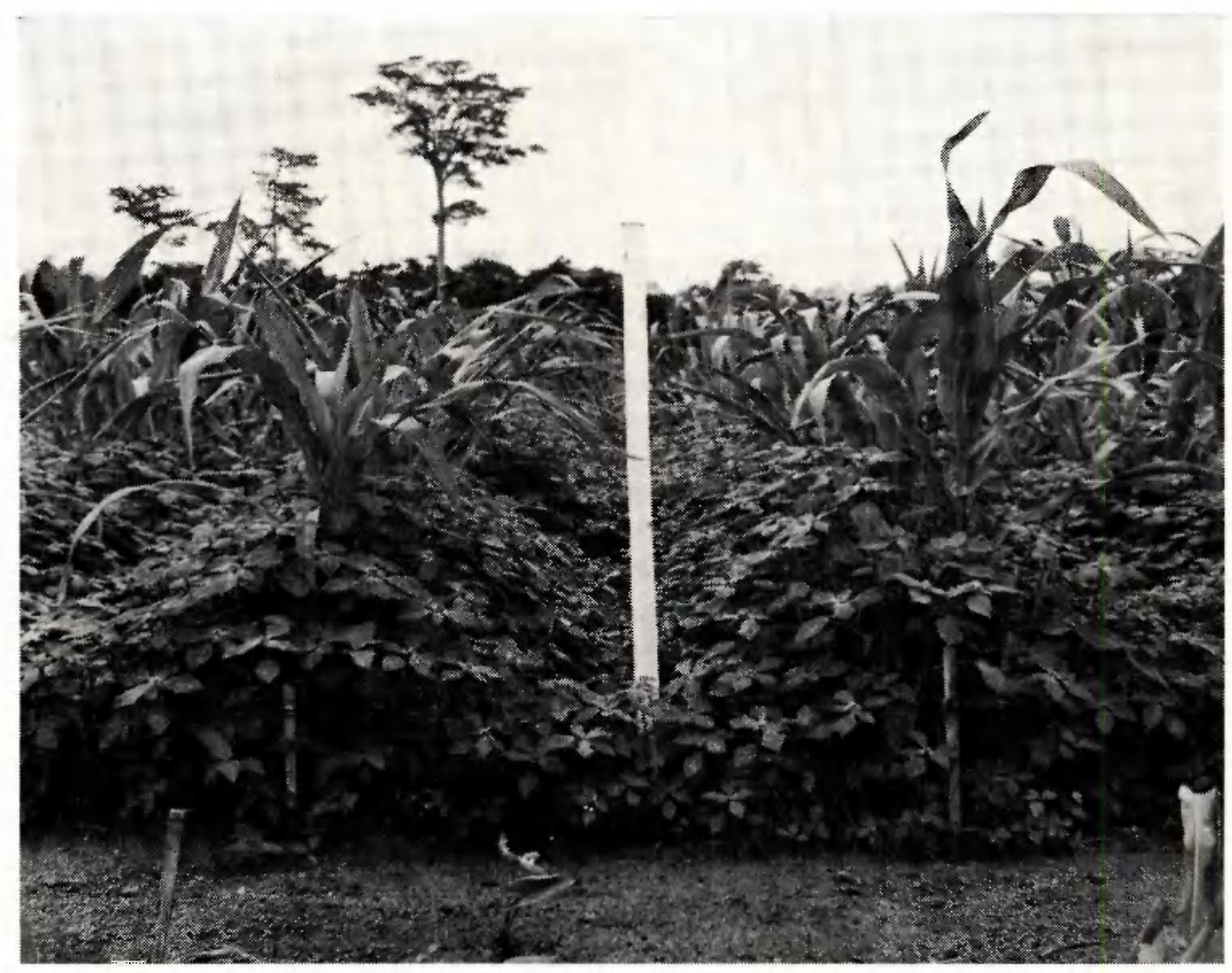

Fig. 4. No weeding, with fertilizers. Note the effect of applying the fertilizers in $15 \mathrm{~cm}$ wide strips on either side of the maize rows.

and combined effect of fertilizing and various weeding frequencies upon the development of cocoa in its early youth and the growth and yield of groundnuts and maize. The results, though quantitativily different, are in accordance with each other as far as they show that on the whole the crop plants benefitted more from reducing the competition by improved weed control than from increasing the available mineral nutrients by application of fertilizers. Introduction of financial figures in the case of groundnuts and maize caused the outcome to be even more convincing.

These results support the author's opinion that often the so much needed progress on small farmers' farms in the tropics cannot be effected only, or even mainly, by resorting to what is generally understood by modernization. To make things worse, such measures require as a rule the investment of considerable amounts of money. Usually the farmer has this money not at his disposal, so that he is compelled to borrow it either at a high interest from money-lenders or, if possible, at a reasonable interest from banks or the government. This increases his risks, great as they are anyhow. Moreover, modernization in this sense takes foreign currency to pay for chemicals, implements, etc., which is withdrawn from reserves badly needed for other purposes. Set against these disadvantages are strong indications, and the results of the experiments described in this paper are among them, that often in the first in- 


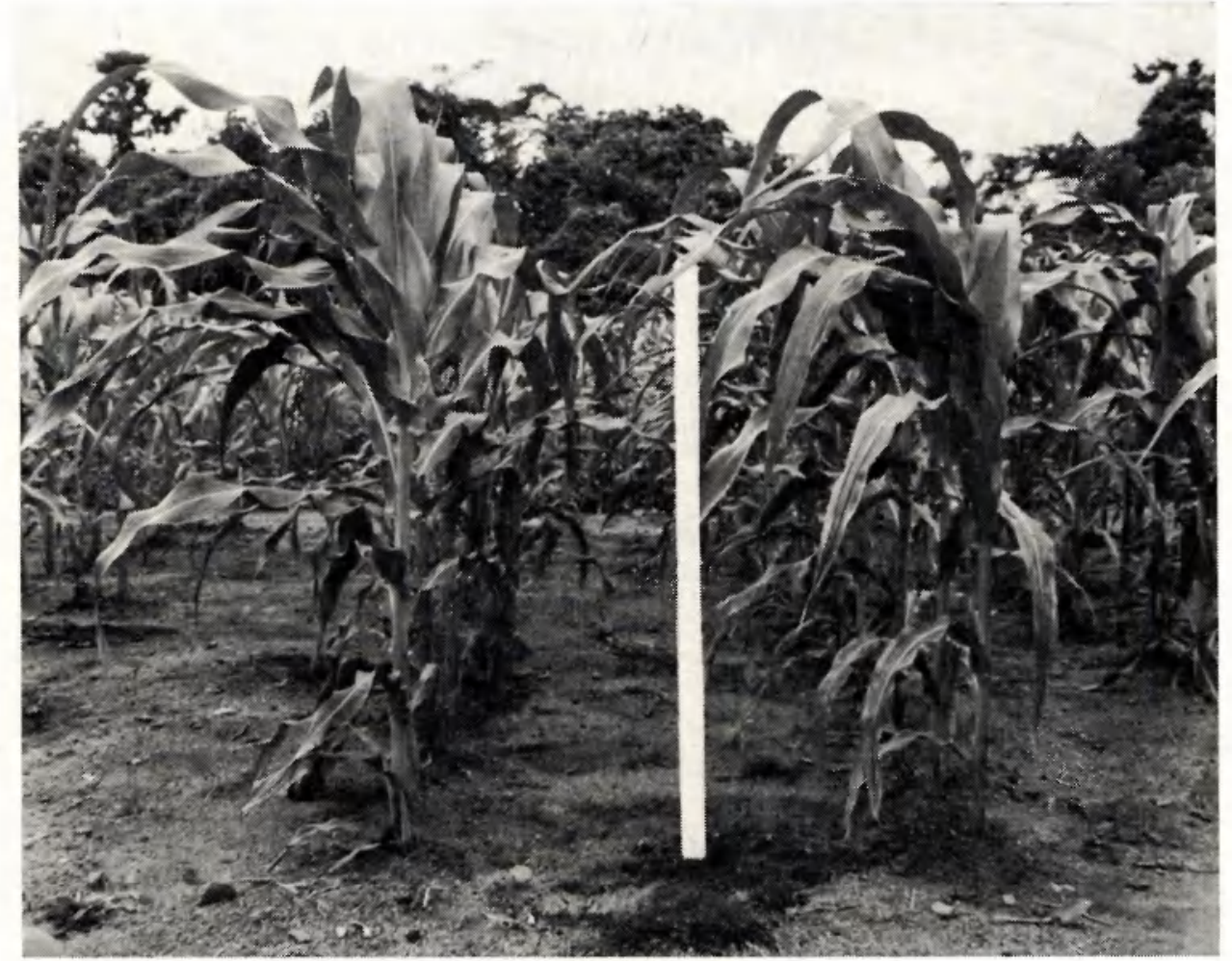

Fig. 5. Good weeding, with fertilizers.

stance more can be achieved in a cheaper way by improving the traditional farming methods by putting more labour in them. More labour does not necessarily cost extra money, since usually there is a vast labour reserve in the rural communities of the tropics. The results of this kind of improvement can be spectacular, as has been shown in the above experiments.

The author wishes to repeat that it would be far from him to reject the so-called modernization of peasant farming in the tropics. His one and only aim is to accentuate the necessity of taking the most obvious and relatively simple measures first, among other things by teaching the farmers how much can be achieved by spending more care on their crops. He is under the impression that in this respect at present with the governments of certain developing countries as well as with some of the international aid organizations a tendency exists to overestimate the value of what is generally called modernization and to underestimate the essentiality of and vast potentialities connected with improved husbandry on peasant farms.

\section{R E F E R E N C E}

RUINARD, J.

1964 Cocoa research in West Irian (West New Guinea). Neth. J Agric. Sci. 12, 89-112. 